\title{
A RESPONSABILIDADE CIVIL AMBIENTAL FRENTE AOS DANOS CAUSADOS PELOS CONDOMÍNIOS URBANÍSTICOS: A CORRETA IMPUTAÇÃO AOS AGENTES ENVOLVIDOS
}

\author{
Elcio Nacur Rezende ${ }^{1}$ \\ Adriano Mendonça Ferreira Duarte ${ }^{2}$
}

\section{RESUMO}

Objetivou-se com este trabalho analisar o problema da delimitação da responsabilidade ambiental em danos causados pelos condomínios urbanísticos. A doutrina então revisada considera que a responsabilidade poderá ser solidária entre os agentes que criaram o risco do empreendimento ou somente daquele que causou o dano, portanto dividindo-se em um campo vasto de teorias. O estudo de casos e revisão bibliográfica foi o método utilizado com o escopo de se provar qual teoria de forma mais adequada, se aplica à relação presente entre meio ambiente urbano e condomínios.

Palavras-chave: Condomínio urbano; Direito Urbanístico; Responsabilidade Civil; Direito Ambiental das Cidades; Dano Ambiental.

\section{ENVIRONMENTAL CIVIL LIABILITY IN DAMAGES CAUSED BY URBANISTIC CONDOMINIUMS: THE CORRECT AGENTS IMPUTATION}

\begin{abstract}
The objective of this work is to analyze the problem about delimiting environmental liability in damages caused by urban condominiums. The revised doctrine considers that the responsibility may be solidary between the agents who created the enterprise risk or only to that one who caused the damage, thus dividing into a vast field of theories. The case studies and literature review was the method used with the scope to prove which theory more properly applies to the relationship between urban environment and condominiums.
\end{abstract}

Keywords: Urban condominium; Urban Law; Civil Responsibility; Environmental Law of Cities; Environmental Damage.

\section{INTRODUÇÃ̃O}

O crescimento dos condomínios urbanísticos representa uma grande preocupação para urbanistas e ambientalistas nos grandes centros urbanos, frente à implantação desordenada e a carência de regulamentação própria.

\footnotetext{
${ }^{1}$ Pós-Doutor, Doutor e Mestre em Direito. Professor do Programa de Pós-graduação da Escola Superior Dom Helder Câmara.

${ }^{2}$ Acadêmico do Curso de Mestrado em Direito Ambiental da Escola Superior Dom Helder Câmara.
} 
Tais condomínios nascem como loteamentos comuns com procedimento já conhecido da lei n. 6766/79 sobre parcelamento do solo urbano, seguido da implantação física que por sua natureza, em todas as suas fases, causa danos ao meio ambiente, como a subtração de espécies nativas e assoreamento de álveos. Logo após, são fechados através de muros e portarias, com a utilização de outros ofendículos como cercas elétricas que não raro provocam o risco e a morte de animais selvagens.

Para os danos causados pela execução das obras surge para os incorporadores a necessidade de reparação e para os riscos a utilização de medidas preventivas. Trata-se de obrigação ex lege expressa na Constituição da República e na Lei n. 6.938/81 que confirmam a máxima ambiental do poluidor-pagador.

Problemas diversos aparecem quando múltiplos atores se encontram envolvidos na ação ou omissão conexa ao resultado danoso, como o caso de empreendedores, proprietários, condôminos, administração condominial e Município. A quem caberá a imputação do fato danoso? Ocorrerá solidariedade entre os envolvidos? Há a subsunção de obrigações de reparar para os casos de aquisição de propriedade?

O objetivo do presente artigo está em encontrar possíveis soluções para os questionamentos acima, através de detida revisão bibliográfica e também de estudo de casos, valendo-se de método dedutivo para tanto.

\section{A Responsabilidade Civil e a Reparação pelos Danos Ecológicos: Generalidades}

A Responsabilidade Civil é um instituto próprio do Direito Privado que estende suas influências também para áreas do Direito Público, como o Direito Administrativo, o Urbanístico e o Ambiental.

O vocábulo responsabilidade possui sua etimologia no termo latino responsum derivado de respondere que remete no Direito Romano arcaico à ideia de devedor, pois a ele se ligava o responsável como uma forma de garantia nos casos de inadimplemento. E conforme se depreende, o termo surgiu sem considerar a ideia de culpa, pois o responsor se obrigava sem discutir qualquer elemento de ordem subjetiva por se tratar a reparação no regime romano da "justa reparação patrimonial" e a justeza compreendida como "equilíbrio 
patrimonial" que quando rompido deveria a qualquer custo ser reestabelecido (STOCO, 2014, p. 179).

A retomada da teoria clássica que coloca a análise do elemento subjetivo em um segundo momento, frente à necessidade da busca do equilíbrio patrimonial na modalidade aquiliana (extracontratual), vem se tornando um exercício comum entre os civilistas de escol, fato que sempre esteve presente no trato da matéria pertinente ao Direito Ambiental (VENOSA, 2009).

É o que se observa da redação do artigo $14, \S^{\circ}$ da Lei n. 6.938/81 que determina ser o poluidor responsável, independentemente da existência de culpa, pela indenização ou reparação dos danos causados ao meio ambiente, portanto, a responsabilidade está para a vítima (meio ambiente) e não para a figura do agente causador (BRASIL, 1981)

Geneviève Viney citado por Paulo Affonso Leme Machado afirma que o instituto da Responsabilidade Civil acompanha o novo saber jurídico, voltado para a justiça e a utilidade social, logo a responsabilidade ambiental é objetiva não por uma simples razão de ser, mas o é frente ao nicho de direitos e bens envolvidos que por serem ambientais, são universais e o ato de poluir representa o confisco do direito de alguém (Apud, 2013, p.404).

Ainda atendendo às especificidades do Direito Ambiental e aos seus princípios mestres como os da Prevenção, Precaução e do Poluidor-Pagador, a responsabilidade ambiental deve ser entendida em duas vias: a preventiva e a reparatória, mostrando-se importante não somente a da reparação ou compensação, pois frente à irreversibilidade dos danos ambientais a via preventiva se mostra eficaz na tutela ao meio ambiente (BEDRAN e MAYER, 2013, p. 51).

No campo da tutela preventiva são encontradas as licenças e autorizações ambientais, e cabe salientar que mesmo quando há a autorização da atividade, poderá ocorrer responsabilização frente aos efeitos da precaução, trata-se da independência das esferas de responsabilização, expressa no parágrafo $3^{\circ}$ do artigo 225 da Constituição da República. São exemplos, os casos reconhecidos em que há obsolescência da técnica aplicada e o nível de degradação que antes era aceitável passa a não o ser, causando assim danos efetivos ao meio ambiente ou risco (BRASIL, 1988).

Os fatos danosos não enumerados em Lei caracterizam também para a Responsabilidade Ambiental, a atuação do "Princípio da Atipicidade da Responsabilidade" que estabelece uma cláusula geral, onde qualquer dano provocado deverá ser reparado, a 
exemplo do que ocorre no artigo 186 do Código Civil, onde aquele que, voluntariamente, causar dano a outrem deverá proporcionar a justa reparação (STOCO, 2014, p.180).

A cláusula geral de responsabilidade correspondente no regime jurídico ambiental está no parágrafo $1^{\circ}$ do artigo 14 da Lei n. 6.938/81 que determina que seja o degradador obrigado, independente de culpa, a reparar os danos causados ao meio ambiente e a terceiros (BRASIL, 1981).

A opção do legislador foi a instituição da cláusula geral, sem determinar ou especificar na lei os tipos de danos, a exemplo do que ocorre na lei civil que considera este elemento como um instrumento de concretização do direito, o que auxilia o aplicador da lei frente a conceitos jurídicos indeterminados como o de dano ambiental (AGUIAR, 2000, p 09).

O dano ambiental é pressuposto para a imputação da responsabilidade nos casos em que há lesão a determinado bem ambiental ou a interesses de terceiros envolvidos e possui amplo significado apresentado pela doutrina, a depender do bem atacado e do meio específico em que este está inserido (LEITE e tal, 2010, p.92).

No caso dos condomínios urbanísticos, os bens evolvidos poderão ser de ordens diversas, como os bens ambientais propriamente ditos (fauna, flora, água) e bens ambientais urbanísticos (ruas e equipamentos públicos), além dos direitos correlatos. Os primeiros determinam danos como a subtração de espécies nativas e a poluição de mananciais de água, já os segundos, lesões ao patrimônio urbanístico como a limitação de acesso a bens públicos e danos ao sistema de circulação viário.

O dano ambiental poderá se manifestar de diversas formas, como a direta em que a ação recai diretamente sobre o bem tutelado, de forma indireta quando a falta de cuidados preventivos leva à degradação e ainda de forma reflexa com os danos provocados a terceiros.

Como grande parte dos danos ambientais ocorrem pelo exercício do direito de propriedade, há de se levantar a questão do abuso deste direito e os danos causados por ele que muito se distinguem dos provocados pelo ato ilícito, pois no abuso os limites estabelecidos pela lei para o exercício do direito são obedecidos, mas o gozo ou a fruição são desvirtuados. (LEMOS, 2008, p. 107).

Torna-se uma árdua tarefa moldar o instituo do abuso de direito para os casos de responsabilidade ambiental por danos, vezes que o instituto em sua matriz civilista pressupõe 
o elemento subjetivo, o que demanda um esforço doutrinário para adaptar o instituto, pois conforme já mencionado, a responsabilidade por danos ao meio ambiente é objetiva.

Contudo, a teoria moderna sobre abuso de direito, desenvolvida por Josserand trouxe questões relevantes acerca da boa-fé objetiva, afastando o instituto do elemento subjetivo, conforme defendido pela teoria dos atos emulativos, surgida na França no início do século XX por construção jurisprudencial (idem, p. 108).

O Código Civil Brasileiro, ao considerar os Princípios da Eticidade e da Socialidade como elementares, adotou em seu artigo 187 a teoria objetiva ao expressar que comete ato ilícito o titular do direito que ao exercê-lo excede os limites impostos por seu fim social ou econômico, a boa-fé e os bons costumes, conforme determina o Enunciado 37 das Jornadas de Direito Civil (BRASIL, 2012).

A Socialidade possui um caráter especial na esfera protetiva dos bens ambientais, qual seja: a função socioambiental da propriedade, instrumento de tutela presente no atual Estado de Direito Ambiental e expresso no parágrafo $1^{\circ}$ do artigo 1.228 do Código Civil. Então cabe a seguinte indagação, se o titular do direito de propriedade o exerce com abuso, ou seja, não cumpre seu dever socioambiental haverá responsabilidade? E se afirmativo qual tipo de responsabilidade?

Não há duvidas, conforme já mencionado, quem em um ordenamento jurídico onde o caráter protetivo do meio ambiente se eleva à categoria de norma constitucional, haverá responsabilidade pelos danos causados a bens ambientais e a terceiros nos casos de abuso do direito de propriedade. Contudo, o parágrafo segundo do artigo 1.228, quando considerado para exegese do tema, causa grande celeuma por adotar a teoria dos atos emulativos que prescinde da culpa (STOCO, 2014, p. 197).

Caso comum em que ocorre o abuso de direito de propriedade, é aquele em que o proprietário se vale de ofendículos, como cercas elétricas e concertinas para a proteção patrimonial. Não raro são encontrados espécies da fauna local presos, mortos ou feridos, como micos, araras, papagaios e outros e se considerado o disposto no parágrafo $2^{\circ}$ do artigo 1.228 do Código deveria ser realizada a apuração de culpa, contudo frente à natureza do bem atacado e a função social da propriedade, a análise do elemento subjetivo será dispensada.

O Enunciado 49 das Jornadas de Direito Civil afirma que a regra constante do $§ 2^{\circ}$ do artigo 1.228 do Código Civil deverá ser interpretada de forma restrita, em harmonia com a função social da propriedade e com o disposto no artigo 187. Ora, seria um disparate o 
Conselho Nacional de Justiça afastar o elemento subjetivo do artigo 187, conforme o determinado no Enunciado 37 e não considerar o mesmo para o 49, portanto, ao trazer o conhecimento da área civil para a ambiental, pode-se concluir que a Responsabilidade Ambiental nos casos de abuso do direito de propriedade será objetiva (BRASIL, 2012)

Assentadas as premissas acima, não há dúvidas acerca da natureza objetiva da Responsabilidade Civil Ambiental no Direito Brasileiro, assim como sua solidariedade, entendimento positivado no artigo 942 do Código Civil e assentado na jurisprudência dos Tribunais Superiores conforme se verá ainda neste trabalho.

Contudo, a doutrina faz a distinção em relação aos efeitos da responsabilidade perante o fato danoso ambiental, a depender do risco criado pela atividade ou da assunção de atividade extremamente danosa, o que levaria a consideração de um risco integral, em que se desconsidera qualquer forma de excludente.

A Teoria do Risco tem seu arcabouço na ideia de sociedade de risco, é o que Caio Mario da Silva já afirmava ser um produto do desenvolvimento industrial incontrolável que determina situações novas com tanta rapidez que fica quase impossível verificar o elemento culpa nas relações de ato-dano. Constata-se então a necessidade de se voltar os olhos da dogmática para a vítima, seja ela uma pessoa, bem ou direito (PEREIRA, 1990, p.35).

A visão clássica trazida pelo civilista se aplica as relações que envolvem dano ambiental, ao se considerar a natureza dos bem tutelados, pois são os mesmos ambientais e espécie de bens difusos que possuem tutela específica e em uma sociedade capitalista, na qual os métodos produtivos assumem riscos diversos, o meio ambiente coloca-se em uma posição de potencial vítima frente aos possíveis danos advindos da atividade industrial.

Frente a tais riscos assumidos e suportados pelos empresários, surgiu na doutrina e jurisprudência a aplicação da teoria do risco criado aos casos de responsabilidade por dano ambiental, esta por sua vez de ordem também civilista, incorporada ao ordenamento jurídico brasileiro pelo artigo 927 do Código Civil, que afirma ser a obrigação de reparar o dano independente de culpa nos casos especificados em lei ou nos casos em que a atividade provocar por sua natureza, riscos aos direitos de outrem (LEITE e AYALA, 2010, p. 131).

A Teoria do Risco Criado admite causas excludentes de responsabilidade que são a culpa exclusiva da vítima, fato de terceiros, caso fortuito ou força maior. Esta teoria não se vincula a obtenção de lucro com o empreendimento, basta a responsabilidade pela criação do 
risco ao bem tutelado, logo com bases nas teorias da sociedade de risco e na justiça distributiva (CANOTILHO, 2003, p. 143).

Conforme se verá na última parte deste artigo, as decisões dos tribunais brasileiros são vacilantes no que concerne a qual modalidade de risco criado adotar para a solução das lides que envolvem dano ambiental, ora se depara com o risco-profissional, onde quem exerce atividade de natureza profissional deve arcar com os fatos danosos advindos da mesma ora com o risco-benefício, segundo o qual aquele que colhe o bônus sofrerá o ônus.

A diferenciação de tais efeitos é de suma importância para a determinação da extensão dos danos nos casos de implantação de loteamentos, em muitos a teoria do riscobenefício se manifesta como a mais justa, como os casos em que há dano moral coletivo, em outros a presença de um risco-proveito continuado, onde aquele que aufere proveito a qualquer tempo, também será responsável, aqui, a responsabilização do proprietário adquirente.

O presente trabalho não irá se aprofundar nas teorias referentes ao nexo causal, por hora cabe a afirmação de que a apropriação pelo Direito Ambiental Brasileiro da teoria da causalidade adequada se torna bastante útil, pois para a apuração da responsabilidade, há de se perquirir a relação das causas e deverá o intérprete avaliar as que realmente foram decisivas para o resultado, evitando assim um regresso ao infinito (STOCO, 2013, p. 229).

Pensar ao contrário é presumir a adoção da teoria do risco integral que representa medida excepcional em um ordenamento que preza pela segurança das relações jurídicas, portanto, o que parece mais acertado é teoria da causalidade adequada, em que no feixe de causas pretere-se a análise das que razoavelmente contribuíram para o dano, seu incremento ou sua manutenção (BEDRAN e MAYER, 2013, p. 57).

A Teoria do Risco Integral foi adotada pela Constituição da República nos casos de acidentes com usinas nucleares (art. 21. Inc. XXIII d'), contudo a Lei n. 6.453/67 que regulamenta a atividade nuclear em território brasileiro, traz em seus artigos $6^{\circ}$ e $8^{\circ}$ os excludentes de responsabilidade da força maior e caso fortuito (BRASIL, 1967).

Para alguns doutrinadores como Maria Helena Diniz, os artigos da Lei de 1967 foram recepcionados, admitindo-se a quebra do nexo causal, contudo para outros como Celso Antônio Pacheco Fiorillo, os mesmos artigos se tornaram inconstitucionais frente à superveniência da emenda constitucional número 49 de 2006 (DINIZ, 2015, p. 693) (2012, p. 404). 
Nos Tribunais brasileiros a aplicação da Teoria do Risco integral tem se tornado uma tendência, como também vem sendo defendido pela doutrina de Antônio Herman Benjamin, citado por José Rubens Morato Leite, para quem o dano ambiental deve ser recomposto em sua integralidade e tal tutela vem da própria Constituição. (2010, p.132)

Frente às teorias da Responsabilidade Civil apresentadas e a conclusão de que as mesmas depois de especializada releitura se aplicam aos casos de Dano Ambiental, resta a verificação de como a implantação dos condomínios urbanísticos pode levar à assunção de lesões aos bens ambientais urbanísticos, bem como sua apuração e responsabilização.

\section{Condomínios Urbanísticos: Regulamentação, Implantação e Licenças}

Os Condomínios Urbanísticos são uma realidade para os centros urbanos, sendo que há décadas vêm crescendo exponencialmente em número e sem regulamentação consistente, frente ao interesse de grandes empreendedores do ramo imobiliário.

O crescimento pode ser verificado mesmo em outros países, como na Inglaterra, país que compartilha com o Brasil os mesmo problemas relacionados às gated communities, são eles: a fundação sócio legal, a governança, os impactos sobre os seus residentes e a ausência de conhecimento produzido sobre esta nova forma de ordenação do solo urbano (ATKINSON, 2004, p. 875).

A ausência de regulamentação para estes condomínios representa um dos grandes desafios do Direito Urbanístico, vezes se tratar de um fato social que demanda regulamentação, contudo esta ainda não ocorreu a par da morosidade do Poder Legislativo que não concluiu a tramitação do Projeto de Lei n. 3.057/00, este responsável por alterar a Lei de Parcelamento do Solo Urbano (Lei n.6.766/79) acrescentando em seu texto a nova modalidade urbanística.

Da Lei de Parcelamento do Solo surgiu uma aparente solução para anomia através de uma adaptação do Loteamento Comum em Fechado, criando aqui uma nova modalidade de ordenação e divisão do solo urbano que é criticada pela doutrina frente às distorções e problemas apresentados por sua instituição, como a inviabilização do sistema viário, a limitação de acesso a bens e equipamentos públicos e a ofensa ao interesse público (DA SILVA, 2006, p. 354). 
O procedimento aplicado para a instituição dos loteamentos é extremamente complexo tendo como seu início o requerimento de informações sobre a área para o Município ou Distrito Federal, seguido da apresentação de várias licenças entre elas as ambientais prévias, de instalação e operação.

A necessidade das licenças ambientais está calcada no grande impacto que o empreendimento poderá causar no meio ambiente, pois é fato que para ocorrer a urbanização de determinada área, haverá subtração de espécimes nativas, alteração topográficas e hidrográficas, bem como impactos diretos e indiretos para fauna e flora.

Todo o processo é representado por duas fases distintas: a fase do arruamento e a do parcelamento propriamente dita, sendo a fase do arruamento prévia à divisão das glebas e é nela que ocorre o maior número de subtração de vegetação nativa para a abertura das vias de circulação e a formação de quadras.

O Plano de Arruamento é elaborado com o fim de trazer melhor organização do espaço urbano, viabilizando o acesso às áreas privadas e comuns e o equilíbrio estético entre as áreas edificadas e não edificadas, sendo que a metodologia de realização e apresentação do plano deverá obedecer além da Lei de Parcelamento do Solo, as normas urbanísticas pertinentes do Município ou Distrito Federal.

$\mathrm{O}$ processo em questão possui forma vinculada e deve se submeter às normas convencionais apresentadas no memorial descritivo, como também àquelas concorrentes, entre União, Estados e Municípios, respeitado o caráter supletivo daquelas expedidas pelo legislativo local (MEIRELLES, 2005, p. 134).

Os projetos de urbanificação apresentados, a depender de cada ente, deverão conter as áreas verdes, projeto completo de drenagem das águas pluviais e servidas - aquelas provenientes do uso comum como lavagens e despejos de piscinas, projetos de arborização e preservação de cobertura vegetal para evitar erosão (Art. $6^{\circ}$ da Lei n. 6.766/79).

Conforme bem se observa, as exigências citadas demonstram os efeitos do Princípio da Prevenção já na fase de planejamento, pois as obras deverão ser fiscalizadas durante a execução do plano de arruamento, esta ação representa um dos instrumentos de tutela do meio ambiente urbano e qualquer desvio, a depender de cada caso, poderá gerar danos.

A segunda fase, ou plano de loteamento, é de suma importância, pois neste momento ocorrerá a divisão das quadras originadas no arruamento em lotes destinados à edificação. Em algumas cidades, aqui, será feita a proposta de fechamento dos loteamentos, anteriormente ao 
registro, com a proposta de construção de muros e utilização de cancelas e portarias. Contudo, na maioria dos casos a proposta de fechamento ocorrerá depois do registro o que demandará também a cessão de uso dos bens comuns interiores ao loteamento.

No registro do loteamento comum, as áreas destinadas ao arruamento e equipamentos públicos são automaticamente transferidas ao domínio público (art. 17 da Lei n. 6.766/79), alguns munícipios exigem escritura pública de doação para tanto, o que é considerado para a balizada doutrina de José Afonso da Silva um erro (2006, p.342).

Quando a proposta de fechamento é formalizada, surge a necessidade da cessão de uso dos bens comuns para o particular, o que viabiliza o fechamento de ruas e privatização dos equipamentos públicos, sendo que na execução das obras de fechamento é muito comum a insurgência de danos e riscos ambientais, pelo desmatamento e a colocação de ofendículos.

Frente à possibilidade de degradação, própria da atividade de implantação do loteamento comum ou fechado, surge frente à tutela do meio ambiente, a exigência de licenças e mesmo em alguns casos de maior degradação, a necessidade de relatórios de impacto ambiental (Art. 2. Resolução CONAMA n. 237/97 e seu anexo 1)

O Licenciamento Ambiental representa um dos mais expressivos instrumentos de controle da Política Nacional do Meio Ambiente, responsável por delimitar, prévia e concomitantemente à execução do empreendimento os efeitos de determinada atividade sobre o meio ambiente. Para a implantação do loteamento não será diferente, pois o caráter degradante da atividade é notório (JELINEK, 2010, p. 09).

A Licença Prévia será exigida logo após a resposta da Administração Municipal acerca da viabilidade do empreendimento, a mesma deverá ser requerida aos órgãos responsáveis estabelecidos segundo a legislação dos três entes federados dado a competência comum de todos sobre a matéria ambiental.

Os objetivos desta licença serão aprovar a localização e concepção do empreendimento, atestar a viabilidade ambiental e estabelecer os requisitos básicos e condicionantes a serem atendidos nas próximas fases de sua implantação (Art. $4^{\circ}-6^{\circ}$ e $8^{\circ}$. Resolução CONAMA n. 237/97).

A Licença de Instalação será exigida pelo oficial no momento do ato registral dos memoriais em cartório, possui como principal função autorizar a execução das obras e condicionar determinantes e limitações às atividades reconhecidas como degradantes. Cabe 
salientar que a autorização concedida na licença prévia não condiciona a mesma decisão para a de instalação frente à natureza dos direitos protegidos, pois, a qualquer tempo, poderão os órgãos de defesa rever a decisão da autorização quando reconhecerem risco ou perigo ao patrimônio ambiental tutelado.

A Licença Operacional é responsável pela autorização da operação do empreendimento imobiliário, após verificar o efetivo cumprimento do disposto nas licenças anteriores, com as medidas de controle ambiental e condicionantes determinados para os casos de reparação (art. 8. Resolução CONAMA n. 237/97).

Conforme mencionado, as licenças representam forte aparato de tutela e o não cumprimento ou adequação do conteúdo de suas autorizações gerará risco em potencial ou mesmo dano ao meio ambiente natural e urbano, sendo que a apuração destas lesões e as margens de reparação vêm sendo tratadas pelos Tribunais brasileiros de diferentes formas.

\section{A responsabilidade objetiva e solidária pelos danos causados pela implantação do loteamento: imputação aos agentes causadores à luz da Justiça por Integridade de Dworkin}

A imputação aos agentes causadores de dano ambiental nos casos de implantação de loteamentos abertos e fechados vem sendo discutida pelos Tribunais em diversos aspectos, seja em relação à própria responsabilização, à extensão da responsabilidade e se há solidariedade ou não.

Os danos ambientais e os riscos apresentados na implantação dos Loteamentos Urbanos Fechados ocorrem com frequência e em diversas formas, podendo lesionar bens ambientais do meio natural ou artificial, sendo exemplos dos primeiros os casos de subtração de espécies nativas acima do autorizado e dos segundos, a criação de obstáculos ao acesso a bens de uso comum como os equipamentos urbanos (DA SILVEIRA et al., 2011, p.135).

Em julgamento de recurso de apelação, nos autos de ação civil pública proposta pelo Ministério Público Estadual em que se discutia a responsabilização do Condomínio Ecológico Village III por danos a área de proteção ambiental, o Tribunal de Justiça do Distrito Federal e Territórios abordou questão referente à extensão da responsabilidade no caso em que houve regularização do loteamento e posterior apuração de danos. 
Os danos ambientais no presente caso foram comprovados por parecer técnico e elaboração de laudo de diagnóstico ambiental, sendo que em esfera de regulação diversa, no caso o Executivo Distrital, foi expedido decreto com o fim de regularizar o condomínio urbanístico em questão. Contudo, entenderam os julgadores que não há de se considerar um ato de regularização na esfera urbanística como elemento mitigador da responsabilidade ambiental nos casos de dano (TJDF - Terceira Turma Cível; Apelação 2001015 005681-7, rel. Des. Wellington Medeiros; j. DJU 15/05/2002, p. 93).

A decisão foi acertada vezes que a regularização do espaço urbano busca atender a um fim social, qual seja o interesse dos moradores em questão, e em nada se relaciona com a responsabilidade ambiental dos empreendedores à época das obras, sendo que estes não compuseram o polo passivo da ação, mas foram apontados como verdadeiros responsáveis e de forma solidária pelo pagamento da indenização e não os proprietários, nem mesmo o “Condomínio".

Os julgadores em questão se valeram da teoria do risco benefício presente na Lei $\mathrm{n}^{\circ}$ $6.938 / 81$, art. 14 , par. $1^{\circ}, \mathrm{c} / \mathrm{c}$ art. $4^{\circ}$, VII que afirma ser responsável pelo dano ambiental o causador do risco pela execução do seu empreendimento, ao identificarem os elementos positivos necessários quais sejam: ação ou omissão, nexo causal e resultado.

A turma de julgadores seguiu o parecer ministerial que se mostrou favorável à tese de que somente ao poluidor que auferiu ganho patrimonial com a implantação do empreendimento e que foi responsável direto pela execução da obra, deverá ser imputada a obrigação de reparação dos danos ao meio ambiente. Como foram reconhecidos vários responsáveis pelo parcelamento da área e do seguido fechamento da mesma, restou determinada a solidariedade entre eles.

Em decisão semelhante, o Tribunal de Justiça de Minas Gerais decidiu acerca da responsabilidade do Condomínio Fechado Vivendas da Serra, pela supressão de espécimes arbóreos acima do previsto em licença de instalação em sede de julgamento de agravo de instrumento interposto pelo Ministério Público Estadual.

A decisão de primeiro grau negou pedido de liminar para a suspensão das obras, bem como a abstenção de quaisquer atos que viessem a criar risco ou danos ao bem ambiental em questão. Em suas razões o parquet, alegou tratar-se de dano incontestável, vezes que há provas não somente do desmatamento em área de proteção, mas também de que o Município 
autorizou subtração e execução de obras, colocando-se em posição solidária frente às obrigações de reparação do dano frente à concessão de licenças irregulares.

O Tribunal em decisão liminar, acertadamente, concedeu a tutela suspendendo a execução das obras do empreendimento, não somente pelas provas, mas também pelo princípio do in dubio pro natura, vezes que os relatórios de dano apresentados pelo Ministério Público informaram que qualquer intervenção na área em questão levaria a danos irreversíveis ao meio ambiente, mesmo que danos ainda não conhecidos (TJMG - Quinta Câmara Cível; AI 1.0000.15.095619-1/001, rel. Des (a). Áurea Brasil; j. P. 09/06/16).

Todos os efeitos da ação foram suportados pelos responsáveis pelo empreendimento sob o mesmo argumento, de que a responsabilidade pela reparação cabe ao executor direto do loteamento que aferiu maior lucro com o empreendimento, mais uma vez adotando a teoria do risco benefício, com a consequente condenação solidária do Município pela concessão indevida das autorizações e por não impedir a execução das obras.

O Superior Tribunal de Justiça vem decidindo ao tratar sobre o tema responsabilidade ambiental e loteamentos pela solidariedade dos envolvidos, tanto os que criam o risco como aqueles que possuem o dever de fiscalização. É o caso do Recurso Especial de n. 1.410.698, cujo relator foi o Ministro Humberto Martins.

Mesmo não se tratando de caso referente a loteamento fechado - condomínio urbanístico, mas sim de loteamento aberto, as razões do voto se aplicam, pois se trata de parcelamento de solo irregular que causou não somente danos ao meio ambiente natural, mas também ao criado, maculando o bem estar dos moradores em questão.

Interessante observar que o STJ confirmou o acórdão na parte que determinou a responsabilidade solidária do Munício de Uberlândia e dos empreendedores a procederem a regularização do loteamento, e entendeu que os proprietários não seriam responsáveis, mas também vítimas frente ao dano reflexo causado pelo dano ambiental urbanístico, este provocado pela privação ao bem estar coletivo, ou seja de se viver em ambiente urbano equilibrado e sustentável.

A corte reconheceu o dano moral coletivo, por se tratar o ambiente urbano saudável e equilibrado de bem extrapatrimonial que ao ser atingido fere uma moral coletiva passível de indenização, logo esta espécie de lesão pode ser mensurada para a reparação patrimonial sem a necessidade de prova do sofrimento, ou mesmo do resultado, pois o que se busca é a 
reparação integral de um dano que em sua origem é ambiental (STJ - 2 ${ }^{\mathrm{a}}$ Turma; REsp 1410698 / MG, rel. Min. Humberto Martins; j. 30/06/15; RSTJ vol. 239, p. 118).

Sobre a responsabilização dos proprietários adquirentes o STJ apresenta entendimentos divergentes, conforme se observa no seguinte voto da lavra da Ministra Eliana Calmon, no Recurso Especial de $N^{\circ}$ 1.328.874 - SP que em sua origem remota possui uma ação civil pública ajuizada pelo Ministério Público do Estado de São Paulo que objetivou desfazimento de loteamento irregular em área de preservação especial, qual seja a Serra do Mar.

A Ministra considerou em sua decisão que conforme repisada matéria discutida na corte, há litisconsórcio passivo entre os causadores diretos do dano na implantação do loteamento e os adquirentes dos lotes, mesmo quando a aquisição ocorrer após o fato danoso, contudo tal litisconsórcio é facultativo frente à solidariedade presente na obrigação de reparar (STJ - 2 ${ }^{\mathrm{a}}$ Turma; REsp 1328874 / SP, rel. Min. Eliana Calmon; j. DJe 05/08/2013).

Trata-se de questão de cunho processual, mas que comprova em sua base a solidariedade presente nos casos de responsabilização por dano ambiental e conforme se observou, não há dúvidas acerca da natureza da responsabilidade ambiental nos tribunais que será objetiva.

A matéria se torna vacilante no que concerne à extensão da responsabilidade que será solidária plena ou terá este efeito mitigado pelo critério do maior lucro auferido, neste ponto há também questão de cunho social a depender dos interessados e responsáveis, quando estes se tornarem também vítimas (dano mora coletivo) e não poluidores, assunto tratado em decisões mais recentes.

A decisão que leva em consideração a figura do proprietário adquirente ao entender que o mesmo sofre ofensa em seu direito de desfrutar de um meio ambiente urbano equilibrado, posicionando-o assim como vítima da ação do poluidor, se coaduna com o conceito de justiça tratado por Dworkin.

A justiça para Dworkin pode ser instrumentalizada pela integridade que representa um ideal político, uma terceira via entre a equidade e a própria justiça, responsável por vincular as ações do Estado e dos agentes morais envolvidos na sociedade em uma coerência orgânica de forma a resguardar o bom andamento comunitário (ROESLER, 2008, p.56). 
Para a atividade jurisdicional são determinantes dois níveis de integridade, um inclusivo em que o juiz deve considerar os princípios, o senso de equidade e o devido processo legal; e o puro, onde os juízes seriam livres para buscar a adequação entre os princípios do direito para assim alcançar a justiça, não somente os princípios postos, mas também os vivenciados pela comunidade (DWORKIN, 2007, p.272).

O ideal de integridade está presente na decisão que determinou os danos morais coletivos e restringiu a extensão da responsabilidade, condenando somente os empreendedores que auferiram lucro com a criação do loteamento. Ora, pensar o contrário seria impor responsabilidade a quem não causou os danos e não se beneficiou em nada com a ação que os resultou.

Em muito se assemelha aos problemas citados por Dworkin quando da execução dos juízos conciliatórios, como o exemplo do doutrinador sobre a comunidade dividida acerca da legalização do aborto e a norma conciliatória de solução imposta que determina que as mulheres nascidas em dias pares possam abortar. Ora, tal norma satisfaz de forma salomônica o dissenso, mas se mostra de forma contrária a um ideal político integro (MACHADO, 2017, p.247).

O mesmo se aplica como crítica ao entendimento que estende a todos os casos de dano ambiental a teria da responsabilidade por risco integral, pois fica aparente a temeridade das decisões que não consideram a integridade política do momento para resolução dos conflitos, afrontando ideais comuns e criando injustiças.

A justiça que encontra fundamentos na integridade importa na ruptura dos critérios já postos, logo pensar a responsabilidade solidária por danos ambientais extensivas a todos os casos, representa afronta aos ideais de justiça presentes no Estado Democrático de Direito.

\section{CONCLUSÃO}

A imputação de responsabilidade por danos ambientais causados por condomínios urbanísticos, mostrou-se no presente trabalho ser um tema atual e que possui divergência de entendimentos tanto na doutrina como nas decisões dos tribunais superiores.

Ao se tentar estabelecer um marco inicial para a fundamentação, conclui-se que é possível a aplicação das teorias gerais da Responsabilidade Civil ao tema, contudo sobre uma ótica especializada, em que autores diversos adaptaram institutos clássicos do Direito Civil 
como o abuso de direito ao Sistema Protetivo Ambiental, reconhecendo a responsabilidade objetiva como teoria central.

A adoção da responsabilidade objetiva para as matérias correspondentes ao dano ambiental é entendimento já consolidado pela doutrina revisada e pelas decisões analisadas, logo, para os envolvidos nos fatos danosos durante a execução das obras de parcelamento do solo e na implantação dos ditos Condomínios Urbanísticos, restou configurada a responsabilidade sem qualquer questionamento de culpa ou dolo.

A extensão da responsabilidade (solidariedade) se mostrou mitigada em decisões que se valeram da teoria do risco benefício, em que proprietários adquirentes foram considerados vítimas frente ao dano urbanístico apresentado pelas irregularidades do loteamento fechado, sendo que nenhum decisum considerou a Teoria do Risco Integral.

Em sua maioria as decisões fixaram a responsabilidade pela indenização para aqueles que auferiram os benefícios do empreendimento, contudo para tal matéria há divergência nos Tribunais, pois em julgado recente, o Superior Tribunal de Justiça entendeu serem responsáveis pelos danos à época do parcelamento, os adquirentes dos lotes, por serem beneficiados continuados do empreendimento.

A obrigação solidária de indenizar ficou estabelecida para a Administração Pública Municipal na doutrina e na maioria das decisões, principalmente nos casos em que houve emissão de atos autorizativos para a implantação do empreendimento em áreas comprovadas de proteção, demonstrando assim ilegalidade.

A par das divergências encontradas, este trabalho pode concluir que a Responsabilidade por Danos Ambientais nos casos de Condomínio Urbanísticos é objetiva, solidária, valendo-se os julgados sobre o assunto, em sua maioria, da Teoria do Risco Benefício o que demonstrou ser medida mais justa frente à imputação da responsabilidade aos agentes envolvidos.

\section{REFERÊNCIAS}

AGUIAR JÚNIOR, Ruy Rosado de. O poder judiciário e a concretização das cláusulas gerais: limites e responsabilidade. 2000 . Disponível em: http://bdjur.stj.jus.br/jspui/handle/2011/470 Acesso em 27/03/2017. 
ATKINSON, Rowland; FLINT, John. Fortress UK? Gated communities, the spatial revolt of the elites and time-space trajectories of segregation. Housing studies, v. 19, n. 6, p. 875$892,2004$.

BEDRAN, Karina Marcos; MAYER, Elizabeth. A Responsabilidade Civil por Danos Ambientais no Direito Brasileiro e Comparado: Teoria do Risco Criado Versus Teoria do Risco Integral. Veredas do Direito: Direito Ambiental e Desenvolvimento Sustentável, v. 10, n. 19, p. 45, 2013.

BRASIL. Ministério do Meio Ambiente. Conselho Nacional do Meio Ambiente - CONAMA. RESOLUÇÃo CONAMA no 237, de 19 de dezembro de 1997 Publicada no DOU n. 247, de 22 de dezembro de 1997. Disponível em http://www.mma.gov.br/port/conama/legiabre.cfm?codlegi=237 Acesso em 13 marco 2017. BRASIL. Poder Judiciário. Conselho da Justiça Federal. Enunciados das Jornadas de Direito Civil. Jornadas de direito civil I, III, IV e V: enunciados aprovados. Brasília: Conselho da Justiça Federal, Centro de Estudos Judiciários, 2012. Disponível em: http://www.cjf.jus.br/cjf/CEJ-Coedi/jornadas-cejAcesso em 14 março 2017

BRASIL. Poder Legislativo. Câmara dos Deputados. Lei 6.453/67. Dispõe sobre a responsabilidade civil por danos nucleares e a responsabilidade criminal por atos relacionados com atividades nucleares e dá outras providências. Disponível em: http://www.planalto.gov.br/ccivil_03/leis/L6453.htm Acesso em 14 março 2017.

BRASIL. Poder Legislativo. Câmara dos Deputados. Lei 6.766/79. Dispõe sobre o Parcelamento do Solo Urbano e dá outras Providências. Disponível em: http://www.planalto.gov.br/ccivil_03/leis/L6766.htm Acesso em 14 março 2017.

BRASIL. Poder Legislativo. Câmara dos Deputados. Constituição Federal de 1988. Disponível em: http:/www.planalto.gov.br/ccivil_03/constituicao/constituicaocompilado.htm Acesso em 14 março 2017.

BRASIL. Poder Legislativo. Câmara dos Deputados. Código Civil. Disponível em: http://www.planalto.gov.br/ccivil_03/leis/2002/L10406.htm Acesso em 14 março 2017.

BRASIL. Poder Legislativo. Câmara dos Deputados. Projeto de Lei 3.057/00. Inclui alterações no texto da Lei $\mathbf{n}^{\circ} \mathbf{6 . 7 6 6}$, de 19 de dezembro de 1979. Brasília. Disponível em: http://www.camara.gov.br/proposicoesWeb/fichadetramitacao?idProposicao=19039 Acesso em 10 setembro 2016. 
BRASIL. Superior Tribunal de Justiça. REsp 1328874 / SP, Brasília/DF rel. Min. Eliana Calmon Pesquisa de Jurisprudência, Acórdãos, 05 agosto de 2013. Disponível em:https://ww2.sti.jus.br/processo/revista/inteiroteor/?num_registro=201102208526\&dt_publicacao=05/08/2013 Acesso em 27 março 2017.

BRASIL. Superior Tribunal de Justiça. REsp 1410698 / MG, Brasília/DF. rel. Min. Humberto Martins Pesquisa de Jurisprudência, Acórdãos, 30 junho de 2015. Disponível em: https://ww2.stj.jus.br/processo/revista/inteir

oteor/?num_registro=201303462603\&dt_publicacao=30/06/2015. Acesso em 27 março 2017.

BRASIL. Tribunal de Justiça do Distrito Federal e Territórios. Apelação Cível. 2001015 005681-7 Brasília/DF. Relator: Desembargador Wellington Medeiros. Pesquisa de Jurisprudência, Acórdãos, 7 março de 2002. Disponível em: https://tjdf.jusbrasil.com.br/jurisprudencia/3121272/apelacao-civel-ac-20010150056817-df?ref=juristabs. Acesso em 27 março 2017.

BRASIL. Tribunal de Justiça de Minas Gerais. Agravo de Instrumento. 1.0000.15.0956191/001 Belo Horizonte/MG. Relator: Desembargadora Áurea Brasil. Pesquisa de Jurisprudência, Acórdãos, 9 junho de 2016. Disponível em: http://www5.tjmg.jus.br/jurisprudencia/pesquisaNumeroCNJEspelhoAcordao.do?numeroRegistro=1 \&totalLinhas=1\&linhasPorPagina=10\&numeroUnico=1.0000.15.0956191\%2F001\&pesquisaNumeroCNJ=Pesquisar._Acesso em 27 março 2017

CAnotilho, J. J. Gomes. Direito Constitucional e Teoria da Constituição, Coimbra: Almedina, 2003.

DA SILVA, José Afonso. Direito Urbanístico Brasileiro. Malheiros Editores, São Paulo. 2006.

DA SILVEIRA, Sebastião Sérgio e SILVERIA, Ricardo dos Reis. Loteamentos fechados: privatização de espaços públicos e escravização dos moradores. Revista Veredas do Direito, Belo Horizonte, ž v.8 ž n.15 ž p.133-147, 2011.

DWORKIN, Ronald. O império do Direito. $2^{\mathrm{a}}$ ed. Editora Martins Fontes. São Paulo 2007.

FIORILlO, Celso Antônio Pacheco. Curso de Direito Ambiental Brasileiro. 13 ${ }^{\mathrm{a}}$ ed. Editora Saraiva, São Paulo. 2012. 
JELINEK, Rochelle. Licenciamento ambiental e urbanístico para o parcelamento do solo urbano. 2010. Disponível em https://www.mp.go.gov.br/portalweb/hp/9/ docs/doutrinaparcel_19.pdf Acesso em 12 março 2017.

LEITE, José Rubens Morato e AYALA, Patryck de Araújo. Dano Ambiental: Do individual ao coletivo extrapatrimonial. Teoria e prática. $3^{\text {a }}$ ed. Editora Revista dos Tribunais, São Paulo. 2010.

LEMOS, Patrícia Faga Iglecias. Meio Ambiente e Responsabilidade Civil do Proprietário: Análise do nexo causal. Editora Revista dos Tribunais, São Paulo. 2008.

MACHADO, Igor Suzano. Comunidade de Princípios e Princípio Realidade: O Juiz Hércules Confuso diante de uma Natureza Ameaçada Veredas do Direito: Direito Ambiental e Desenvolvimento Sustentável, v.13. n.27.p. 243-265 . Setembro/Dezembro de 2016.

MACHADO, Paulo Affonso Leme. Direito Ambiental Brasileiro. 21 a ed. Editora Malheiros, São Paulo. 2013.

MEIRELLES, Hely Lopes. Direito de Construir. 9ª ed. Malheiros Editores, São Paulo. 2005. PEREIRA Caio Mario da Silva. Responsabilidade Civil. Editora Forense, Rio de Janeiro. 1990.

ROESLER, Ednilson José. Justiça como integridade: interlocuções entre Dworkin e Hegel. 2008. Dissertação de Mestrado. Pontifícia Universidade Católica do Rio Grande do Sul.

STOCO, Rui. Tratado de Responsabilidade Civil. 10ª ed. Revista dos Tribunais, São Paulo. 2014.

VENOSA, Sílvio de Salvo. Responsabilidade Civil. Carta Forense 69/12, fevereiro/2009. Disponível em: http://www.cartaforense.com.br/conteudo/entrevistas/ responsabilidadecivil/3463 Acesso em 14 março 2017. 